\title{
口唇口蓋裂患者の耳疾患と聴力障害について
}

\author{
*辻 忠良 - 三村 保 - 松矢篤三・西村敏治 - 宮崎 正 \\ $* *$ 山口邦夫, $* * *$ 曾我部律夫・戸堂新八郎
}

\section{Ear disease and hearing loss in patients with cleft lips and pa?ates}

\author{
*Tadayoshi Tsuji - Tamotsu Mimura - Tokuzo Matsuya - Toshiharu \\ Nishimura - Tadashi Miyazaki \\ **Kunio Yamaguchi, ${ }^{* * *}$ Ritsuo Sogabe $\cdot$ Shimpachiro Todo
}

緒論

口蓋裂患者に耳疾患を有するものが多いことは, 1893 年にGuntsmann ${ }^{1}$ が報告して以来多くの研究をみる ${ }^{2), 3)}$, 本症は勫咽腔周辺部の形態異常のために, 同部の炎症な どが経耳管的に中耳に波及しやすくそのために中耳炎症 の反復再然や慢性化，また後遺症としての中耳病変，鼓 膜癒着等を生じ,ひいては伝音性の聴力障害を生じるも のであると考えられている。

しかし，今までの諸家の報告においても聴力障害の発 現頻度, 破裂形態・手術時期などとの関係についてはい まだ一致したものはなく，その発生原因，予防法につい ても明確な解答は得られていない。

口唇・ 口蓋裂患者の手術後の機能回復, 特に言語回復 には聴力によるフィード・ハックが重要であり，とくに 口蓋裂形成手術を終え言語治療を行な52才前後は，言 語発達のらえでも話しことば習得完成の時期と重なるた め, 耳疾患, 聴力障害について十分な注意を向ける必要 がある.

かかる見地より，われわれは口蓋裂形成手術を受け言 語治療のために来院した患者に対し，耳鼾科的検診によ

* 大阪大学齿学部口曌外科学第一講坐（主任: 宮崎 正 教授)

** 大阪大学歯学部口腔外科学第二講座（主任：川勝 蜸 作 教授)

****大阪市立小児保健センター耳與咽喉科（主任：筸我部律 夫)

* Ist Department of Oral and Maxillo-Facial Surgery, Osaka University Dental School (Chief : Prof. Tadashi Miyazaki)

** 2 nd Department of Oral and Maxillo-Facial Surgery, (Chief : Prof. Kensaku Kawakatsu)

*** Depatment of Oto-Rhino-Laryngology, Childrens Medical Center of Osaka City (Chief : Dr. Rithuo Sogabe)

受付 昭和 46 年 4 月 15 日
り耳疾患を把握すると共に聴力検査をあわせ施行し，現 状を分析，口唇口蓋裂患者の耳疾患を少なくするための 足がかりとしたいと考えた。

\section{対象ならびに方法}

検査刘象は昭和 42 年 4 月より昭和 43 年 3 月まで

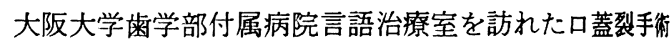
後の患者より無作為に抽出した 93 名である.

年令分布は表 1 に示すごとく，2 才乃至 5 才の患喤 75\%を占めていた。

破裂形態で分類すると, 唇・顎・口蓋裂患者 65 名， 口蓋裂のみの患者 28 名であった。

検査は大阪市立小児保健センター耳鼻咽㮢科で行ない, 問診ならびに耳・番・咽頭の診査ののち聴力検查を葹 した。鼓膜所見は混濁，陥凹，癒着，般痕形成，穿孔を 認めるものを異常とし, 軽度, 中等度, 高度病変と分類 し更に慢性中耳炎を加えた.聴力検査は可能な限り play audiometry〜standard audiometry を行ない, 年令板 その理由で自覚的検査の不能な者は startle response audiometry により行なった。検査周波数は 250,1000 ，
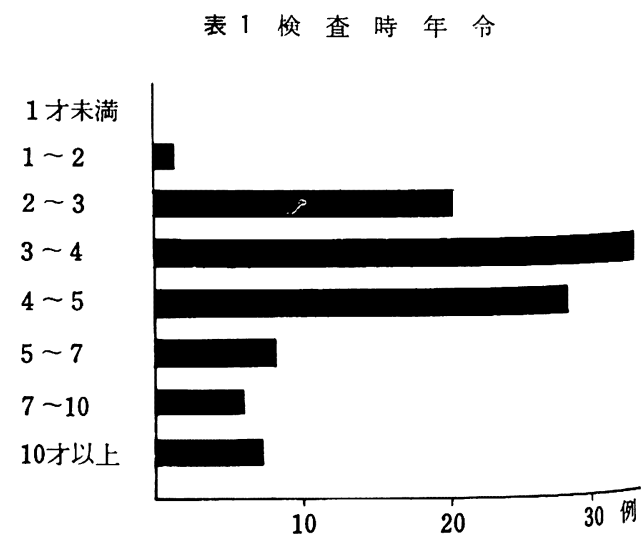
$2000 ， 4000,8000 \mathrm{~Hz}$ であるが，会話音域の平均値によ り聴力損失を検討した。

問診により口蓋裂形成術前後を問わず中耳炎の既往歴 を有するものは表 2 に示すごとく 55 名 $(59 \%)$ に及ん だ.

$$
\text { 結果 }
$$

手術前後の罹患率を比較すると表 3 のごとく手術前で は 50 名 $(54 \%)$, 手術後では 23 名 (25\%) となり手術 後に減少する傾向が伺われる，手術前後を通じて中耳炎 の既往歷の無いものは 37 名 $(40 \%)$ で，手術前に既往 があって術後再発をみなくなったものは $37 \%$ であった。 一方，手術後も再発を文たものは慢性中耳炎の 4 名を加 えて 18 名 (20\%) であった。

破裂程度と中耳炎既往の頻度については，口蓋裂のみ のものでは 15/28 (54\%), 唇・䫜・口蓋裂では $36 / 65$ (55\%）と差は無かった。

鼓暯所見の結果は表 4 に示すように，正常ないし軽度 病変は 144 耳 $(76 \%)$, 中等度ないし高度病変は 36 耳 (21\%)，穿孔のある慢性中耳炎は 6 耳（3\%）であった. 特に現在慢性中耳炎を認好るものは93 名中 4 名 (4.3 \%)となり一般小中学校検診時にみられる $0.6 〜 0.7 \%$ の罹患率に比し著しい高頻度となっている.

中等度以上の鼓膜病変を有するものを破裂状態によっ て分類すると，唇・顎・口蓋裂では $37 / 130$ 耳 $(28 \%) て ゙$,

表 2 中耳炎の既往歴

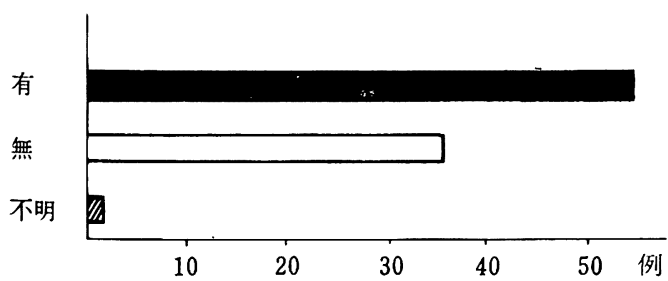

表 3 中耳炎の既 往 歴 (術前…術後の比較)

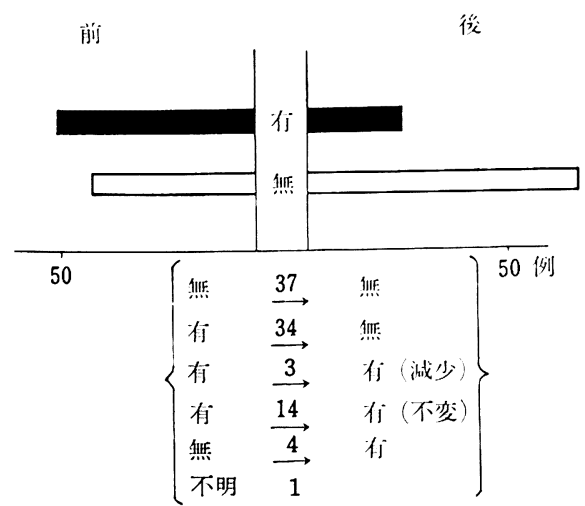

口蓋裂のみでは $5 / 56$ 耳（9\%）を認め, 破裂程度の大な る程, 部膜所見で高い父患率を示しているのが認められ た. 特に慢性中耳炎の 4 名はいずれも唇・顎・口蓋裂で あった。

片側性唇・顎・口蓋裂患者で，破裂側と健側の鼓膜所 表 4 豉膜 所見

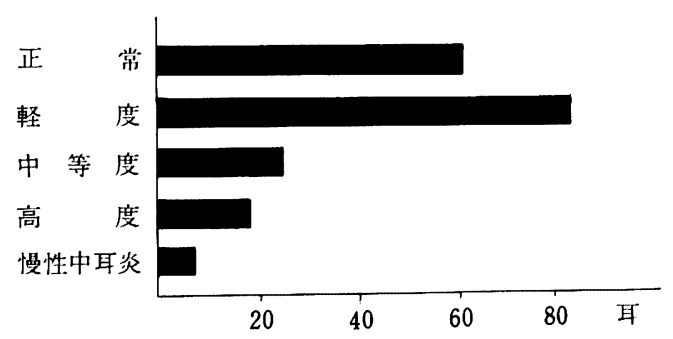

表 5 破裂程度と做膜所見

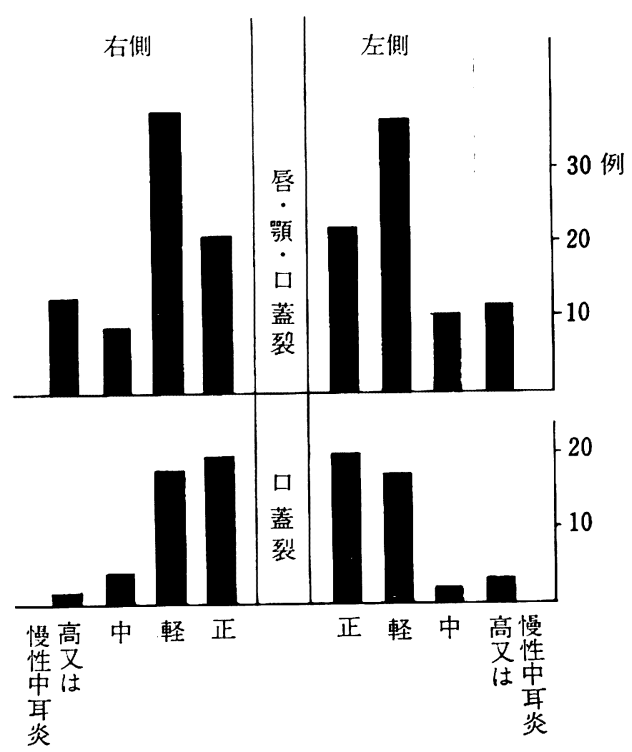

表 6 手術年令と鼓膜所見 (一耳単位)

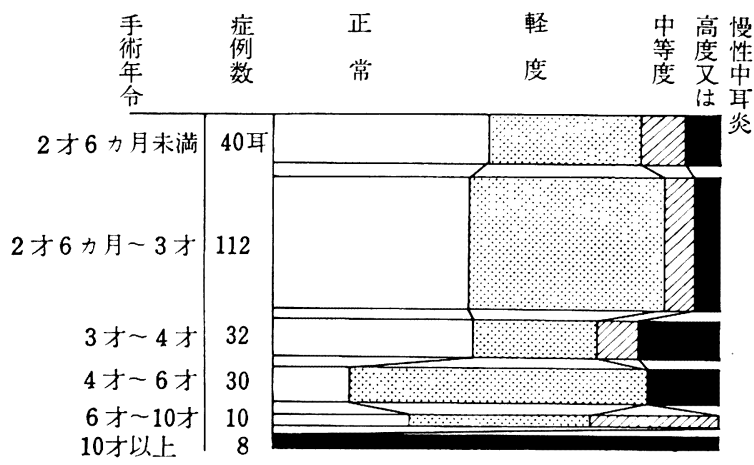


表 7 聴力損失（会話音域平均 $\mathrm{db}$ )

\begin{tabular}{r|r|r|r|r|r}
\hline 左 & $0 \sim 10$ & $11 \sim 20$ & $21 \sim 30$ & $31 \sim 40$ & $41 \sim 50$ \\
\hline $6 \sim 10$ & 14 & 1 & & 1 & 1 \\
$11 \sim 20$ & 6 & 38 & 1 & 2 & \\
$21 \sim 30$ & & 2 & 14 & 2 & \\
$31 \sim 40$ & 1 & & 2 & 6 & \\
$41 \sim 50$ & & & 1 & 1 &
\end{tabular}

表 8 聴力損失（会話音域平均 $\mathrm{db}$ )

唇・顎・口蓋裂群

\begin{tabular}{r|r|r|r|r|r}
\hline 左 右 & $0 \sim 10$ & $11 \sim 20$ & $21 \sim 30$ & $31 \sim 40$ & $41 \sim 50$ \\
\hline $0 \sim 10$ & 12 & & & 1 & 1 \\
$11 \sim 20$ & 4 & 21 & & 2 & \\
$21 \sim 30$ & & 1 & 12 & 2 & \\
$31 \sim 40$ & 1 & & 2 & 5 & \\
$41 \sim 50$ & & & & 1 &
\end{tabular}

口蓋 裂 群

\begin{tabular}{r|r|r|r|r|r}
\hline 左 & $0 \sim 10$ & $11 \sim 20$ & $21 \sim 30$ & $31 \sim 40$ & $41 \sim 50$ \\
\hline $0 \sim 10$ & 2 & 1 & & & \\
$11 \sim 20$ & 2 & 17 & 1 & & \\
$21 \sim 30$ & & 1 & 2 & 1 & \\
$31 \sim 40$ & & & & & \\
$41 \sim 50$ & & & & &
\end{tabular}

見を対比した結果は略同じ值を示し相関性は認めなかっ た。

次に口蓋裂形成手術時期と豉膜所見では，表 6 のごと くで6才以上で手術をらけたものに中等度ならびに高度 病変を有するものが多く，中でも10 才以上まで放置さ れた症例では全耳が高度または慢性中耳炎であった。

聴力検查の結果では会話音域平均て聴力損失が両耳と も $20 \mathrm{db}$ 以内のものは 59/93 名（63\%）であり，一側ま たは両側耳とも $21 \mathrm{db}$ 以上の聴力損失を有するものは 34 名 $(37 \%)$ であった。これは小中学校における聴力ス クリーニングテスト $20 \mathrm{db}$ 聴取の不合格者が 1 1.5\% であるのに比し高頻度である. 最も聴力の悪いものは右 $43 \mathrm{db}$, 左 $33 \mathrm{db}$ で両耳共 $31 \mathrm{db}$ の損失を有するものは 7 名（\%）であった。これらは全例伝音性難聴と考えら れ, 中等度ない儿高度感音性難聴と思われる症例はみら れなかった。

聴力障害と破裂状態との関係は, 唇・顎・口蓋裂で両 耳共 $21 \mathrm{db}$ 以上の損失を有寸るものは 22/65 名 (34\%), 口蓋裂のみでは $4 / 28$ 名 $(14.3 \%)$ と破裂程度の強い方 が損失も大きい傾向がみられた，特に難聴の高度なもの は大部分が唇・頡・ロ蓋裂であった。

\section{考察}

口蓋裂患者の耳疾患ならびに聴力障害は，正常人に比
し高頻度であると報告しているものが多い. Meissner $(1939)^{4)}$ は2 213 名の耳診査の結果, 正常耳を有するすの は $17 \%$ のみで, 他は何らかの障害を有し, 万ち7\% К

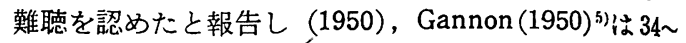
44\% に難聴を認めている. Sataloff ら (1952) (1) $^{4}$ 全例 に鼓膜疾患を認め, 正常聴力を保持しているのは $3 / 30$ 名にすぎないと報告している。一方 Skolnik (1958)》珄 401 例中 $39 \%$ に難聴を認めるが, その半数以上は軽度、 約 $4 / 1$ が中等度で, 高度難聴は $3 \%$ にすぎないと報告し ている.

今回のわれわれの結果も Skolnik にほぼ類似してお り，一側または両側 $21 \mathrm{db}$ 以上の聴力損失を有するもの は $37 \%$ であったが， らち両側共 $31 \mathrm{db}$ 以上の損失を示 するのは $7.5 \%$ であった. しかし鼓膜所見では Graham? が $50 \%$ 前後の異常を報告しており，われわれの結果と やや異なっている.

検查年令について Skolnik の報告では耳疾患は生後 1 年までの乳児で $6 \%$ ，学令期前の幼児で $27 \%$ ，学令期 のもので $68 \%$ と 8 才頃までは增加の傾向をとると述へ，

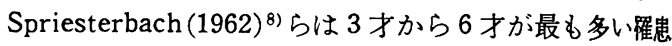
率を占めていると報告している. Tangen (1960) $)^{9}$ は 22 例を follow up した結果, 聴力障害は年と共に変化し, 必ずしも不変なものではないと述べている。多くの研究 者が 2 才 25 才の範囲で検查しており，今回のわれわ れの対象者と類似し 2 才以前の耳検査のむずかしさから みれば当然と考えられる。

口蓋裂患者の耳疾患率の高い原因としては，一般に eustachan tube からの感染が考えられる。 口蓋裂患者 では食物の與下動作が異常で鼾腔に食物の流入があり, まず耳管開口部に粘膜の炎症が起り，中耳に感染か波及 すると考えられている。 また， m. levator veli palatini， m. tensor veli palatini は耳管の開閉に関与していると いわれ，口蓋裂の症例では筋が側方に偏位し異常運動を するために感染を助長させると考えている者も多い。

口蓋裂形成手術によると考える者もあり, House $(1964)^{10}$ は手術後般痕により eustachan tube の機能を 障害した症例に高頻度に中耳疾患を認めたと報告し，ま た多くの耳鼻科医は翼突鈎破折と関係があるとの印象索 持っていると報告している11).

しかしこれらの研究では口蓋裂手術, 鼻咽腔の状態, 口蓋扁桃またはアデノイドの摘出並びに破裂状態との関 係については未だ不明確な現状であろう。われわれ情 咽腔閉鎖機能が完全になるまでは感染の可能性が高いと 考え, 手術前後の中耳炎の頻度を比較した。術前と術後 の期間が等しくないために今回の結果がそのまま正しい とはいえないが，手術時期による鼓膜所見の差をも考虑 すると術後は減少するものと思われる.

Pennbacker は口蓋裂を有なない先天的軟口蓋機能不 全の症例にも $25 \%$ の聴力障害を認めたと報告している 
こととあわせて番咽腔閉鎖不全そのものが，耳疾患に深

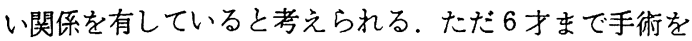
せずに放置した症例では，家族が耳甪科の疾患に対して も無関心で十分な治療を受けさせなかったなと，生活環 境, 衛生思想の要素も含まれていると考えられる。しか 乙同様に鼻咽腔閉鎖不全を有する唇・顎・口蓋裂患者と 口蓋裂のみの患者を比較して, 鼓膜所見, 聴力損失共に 前者の方が高頻度であることは，鼻咽腔閉鎖不全以外の 要因の介入をも考えなければならないことを示唆してい るといえよう。

乳幼児期の聴力障害と言語機能との関係については今 回言及できなかったが，これは口蓋裂言語障害の言語改 善には，鼻咽腔閉鎖機能の獲得，悪習慣の unlearning など種々の条件が加味されるためか, 聴力障害と言語機 能回復の程度に必ずしも相関性を認め得なかったもので ある. しかし言語習得時期におけるフィード・バック機 構の障害は，たとえ経度でも観過されてはならず，この 時期の耳疾患には最大の考虑が払われるべきであると考 える.これの予防に Randa11 ら ${ }^{11)}$ は中耳の微細な観察 によって abnormal material を除去し, 中耳の通気性 を高めることによって Pneumozation を図ることが有効 であると述べているが，現状では早期発見・早期治療が 最も重要であろら.われわれはこの点をさらに追求分析 をつづけ，この疾患に対する予防にまで発展させたいと 考えており，今後の研究を待ちたい.

\section{総括}

口唇・口蓋裂患者の治療に際し, 耳疾患, 聴力障害の 罹患率の高いことが報告されているが，最近本邦におけ る研究結果の報告は少い，われわれは，口唇・口蓋裂患 者におけるこれら疾患の現状を分析し今後の治療に役立 てる目的でこの研究を行なった。

対象は大阪大学歯学部付属病院言語治療室を訪れた口 蓋裂手術後の患者より無作為に抽出した 93 名である. 検查は大阪市立小児保健センター耳鼻咽喉科で, 耳鼻咽 頭の診査と聴力検査を行なった.

結果は次のとおりである.

1. 中耳炎の既往歴を有するものは $59 \%$ におよび手
術前後により羅患率に差異を認めた。

2. 鼓膜所見では中等度以上の病変を有するものは $24 \%$ におよび，また慢性中耳炎罹患者は93 名中 4 名 (4.3\%) で最近の一般小中学校検診時にみられる 0.6 $0.7 \%$ に比し著しく高頻度であった．唇・顎・口蓋裂患 者と口蓋裂のみの患者の間に靖膜所見で差を認めた。ま た手術時期と鼓膜所見にも関連性が認められた。

3. 聴力検查の結果では一側あるいは両側耳共 $21 \mathrm{db}$ 以上の損失のあるものが $37 \%$ に認められ，小中学校の 聴力スクリーニングの成績 $1 \sim 1.5 \%$ に比し著しく多か った。また破裂形態による差異が認められた。

これらの結果より本邦における口唇口蓋裂患者の治療 に際し，耳疾患について十分な考虑が払われるべきであ る.

\section{文献}

1) Guntsman, A. H. : Zur prognose und behandlung der angeborenen Gaumendefekts. Monatsschr ges Sprachheilk 1893.

2) Graham. M.D. : A longitudinal study of ear disease and hearing loss in patients with cleft lips and palates. Annals Otolaryng Rhinol Laryngol 73 : 34471964.

3) Pannbacker, M. : Hearing loss and cleftpalate. Cleft Palate J 6: 50-56 1969.

4) Meissner, K.: Ohrerkrankungen beigaumenspalten. Hals-Nasen u Ohrenarzt (Teil I) 30:6 1936.

5) Gannon, T. : A study of effect of certain surgical variables on the auditory of fifty cleft palate children. M.A Thesis University of Washington 1950.

6) Sataloff, J. et al: Hearing Loss in Childrenwith Cleft Palated. Arch Otolaryrg 55:61 1952.

7) Skolnik, E.M. : Otologic evalution in cleft palate cases. Laryngoscope 68:1908 1958.

8) Spriestersbach, D.C. et al : Hearing loss in children with cleft palates. Plast Reconstr Surg $30: 336-347$ 1962.

9) Tangen, G.IV.: An otologic evaluation and cleft children. M A thesis University of Minnesota 1960.

10) House, I.H. : Current management of hearing loss in clildren Amer J Dis child 108 : 677-696 1964.

11) Stool, S. E. et al : Unexpected ear diseasein infants with cleft palate. Cleft Palate J 4 : 99-103 1967. 